\title{
What are the factors and needs promoting mobility-as-a-service? Findings from the Swiss Household Energy Demand Survey (SHEDS)
}

\author{
Raphael Hoerler ${ }^{1 *}$, Anna Stünzi ${ }^{2}$, Anthony Patt ${ }^{3}$ and Andrea Del Duce ${ }^{1}$
}

\begin{abstract}
Mobility-as-a-Service (MaaS) is a service that supports customers' transportation needs by providing information and ticketing for a multitude of transport modes in one interface; thus, buy potentially fostering multimodality and public transport, it represents an important lever to reduce negative transportation impacts such as emissions and congestion. By means of an online survey conducted in Switzerland, we try to understand potential user needs as well as factors that would motivate the use of MaaS. Comparing the openness to use MaaS for specific trip purposes like commuting and leisure activities, we find the lowest level of openness for commuting and the highest for weekend leisure trips. Intention to reduce car usage was positively related to openness to MaaS in commuting. On the other hand, factors that positively influence openness to using MaaS for leisure activities include a higher education degree, experience with carsharing and the use of transport-related climate policy announcements directly affecting consumers. These findings suggest focusing specifically on either commuting or leisure activities when designing policy measures.
\end{abstract}

Keywords: Mobility-as-a-service, Influential factors, Peer effect, Policy recommendations, Logistic regression, User needs

\section{Introduction}

Mobility is a basic need of society in that it serves as a connection between spatial structures that enables commuting to and from the workplace as well as leisure trips, ultimately driving industry and society forward. The demand for mobility is steadily rising while simultaneously posing serious environmental and societal challenges such as local pollution, congestion and greenhouse gas emissions. Mobility-as-a-Service (MaaS) is a new concept that could address these challenges: a platform providing customers with a holistic service that enables the booking and planning of routes with just one

\footnotetext{
* Correspondence: raphael.hoerler@zhaw.ch

'Institute for Sustainable Development, Zurich University of Applied Sciences (ZHAW), Technikumstrasse 9, 8401 Winterthur, Switzerland

Full list of author information is available at the end of the article
}

app that includes all mobility offers, such as buses, trains, carsharing, ridesharing or bike-sharing. Sufficiency principles such as the sharing of cars or rides are an integral part of MaaS and thus have the potential to foster a transition towards sharing and reduction of car use, potentially fostering car-free households and the reduction of the total vehicle kilometres driven [33, 41, 45]. Such schemes could prove particularly useful in reducing vehicle kilometres driven when used for covering "last-mile" situations and efficiently connecting users to public transport hubs. Further, MaaS concepts might act as enablers for alternative electric drivetrain technologies by reducing common hurdles such as higher purchase costs, range anxiety and mistrust towards new technologies due to lack of experience [43]. MaaS could thus prove important in reducing $\mathrm{CO}_{2}$ emissions and 
improving quality of life through reduced car usage [17]. Wilson et al. [55] foresee the greatest potential of MaaS in $\mathrm{CO}_{2}$ emission reduction from transport as well as transformation capabilities created by the combination of electric mobility and MaaS.

To date, a few studies have analysed the use patterns and behaviour of carsharing users, finding that carsharing could indeed serve a large share of current travel demand, especially by bridging gaps in existing public transportation networks $[4,5,11,53,57]$. Lempert et al. [27] further investigated differences in travel patterns between one-way and two-way carsharing in Vancouver, Canada, concluding that participants of a two-way carsharing service plan their trips more in conjunction with public transport. The potential impact of MaaS on the mobility system and willingness to pay and its relevance to public transport are also increasingly being investigated $[20,34,40]$. Still, to date, very little is known about the general attitude and needs of society regarding these services. Hoerler and Hoppe [23] and Hoerler et al. [22] analysed the openness of commuters in Basel (Switzerland) towards car- and ridesharing as well as the openness of mobility-related stakeholders towards MaaS. They found that the openness of the general public to using these new services is still very low, although mobility-related stakeholders would be open to actively supporting such proposals. Further, the literature investigating user needs is still sparse. Especially when considering MaaS and its strong user focus, a better understanding of user needs would help in providing targeted services and achieving more widespread adoption and diffusion of these new mobility services. This paper explores the needs and expectations of potential users in order to identify ways for increasing openness to using MaaS services.

Mobility needs differ for commuting, short weekday leisure trips and weekend trips. Separately analysing these three travel situations, the present paper will elaborate: i) the demographic characteristics that are relevant to openness to using MaaS and ii) the characteristics that MaaS (also referred to as a combined mobility service within this paper) needs to have in order to achieve higher acceptance and usage rates. Accordingly and based on literature about MaaS, we derive six hypotheses. In addition, two further hypotheses are then derived to discuss behavioural mechanisms, which are experimentally tested with respect to their potential to increase openness to using MaaS: iii) whether peer effects play a role in stated openness to using combined mobility services and, last, iv) whether respondents differ in openness to using a combined mobility service when they are informed about future policy measures. These research questions are then investigated through the statistical analysis of a representative survey of Swiss households within the Swiss Household Energy Demand Survey (SHEDS) 2018.

The paper starts with an overview of current challenges and experiences with MaaS and reviews the literature pertaining to the two behavioural mechanisms tested in this study. The section that follows sets out the survey design and regression model used to estimate factors that might influence openness to using MaaS. The results are presented and discussed in Sections 4 and 5, respectively. Finally, the study provides conclusions and recommendations for future research on how to effectively increase the adoption of MaaS by the general public.

\section{Background}

\subsection{Openness to using MaaS - current challenges and experiences}

MaaS is a relatively new concept. One of the first comprehensive descriptions of it is presented in a study by Hietanen [19]. He summarizes the function of MaaS as a "mobility distribution model in which a customer's major transportation needs are met over one interface and are offered by a service provider" ([19], p. 3). Heikkilä [18] further popularized the term MaaS, spreading the notion across the personal transport sector. The core idea is to integrate various transport options into a single mobility service through a digital interface. It is accessible on demand and thus supposed to increase the flexibility of public transport as well as provide alternatives to the private car [29]. The digital interface, a medium commonly used with smartphones or web pages, allows trip planning, booking, ticketing, payment and real-time information provision that can be personalized and customized to meet the end users' needs [25]. The transport options offered within MaaS are not limited to public transport but aim to include taxis, carsharing, ridesharing, and bike-sharing as well as other forms of mobility services. This also allows for a multi-modal approach to mobility in which various trip options are available to the user, who can then make choices based on personal needs. A comprehensive overview of MaaS definitions is provided by Sochor et al. [46].

At the time of writing, only a limited number of studies have considered the openness of the general public to using MaaS. Sochor et al. [47] examined users' motives for using the UbiGo service - a MaaS project that has been trialled in Gothenburg - before and after they took part in a six-month field operational test. They conclude that the users' predominant motive before taking part in the trial was mainly curiosity, indicating that MaaS users could be considered early adopters [47]. During and after the experiment, the participants had the possibility to test living without a private car. Following that, the motives convenience and flexibility 
increased substantially in contrast to the motives indicated before participating in the field test. The aim of city planners and the government to reduce private car usage converge with the results of this MaaS field test since the participants rated their use of carsharing and rental services as more frequent and their attitudes towards these services as more positive than before. Similarly, Matyas \& Kamargianni [31] find through a stated preference survey covering the Greater London area that respondents, once decided for a MaaS bundle, would be willing to try sharing modes previously not used. However, Sochor et al. [47] also identified issues that would need to be addressed for a successful implementation of MaaS. These include the possibility of making a profit, service providers losing their brand exposure (as they were all summarized under UbiGo), defining a payment procedure that suits low-income households, uniting already available travel services and issues related to smartphone technology, such as battery life, network access and proof of a valid ticket.

A new study by Schikofsky et al. [42] investigated the role of values in acceptance of several different hypothetical MaaS plans, finding that a mix between communicating functional benefits and emotional values would be most effective. Also the feeling of being related to an associated user group could spur adoption.

Ho et al. [20] conducted a stated choice study of 252 individuals in Sydney, Australia, to investigate the uptake and willingness to pay for MaaS (the transport options included public transport, carsharing, taxi and UberPOOL). In their study, the frequency of current car usage significantly influenced the potential uptake level, with the frequent car user (three or 4 days per week) being most open towards MaaS, the infrequent car user (one or 2 days per week) slightly less so, the very frequent car users (five to 7 days per week) exhibiting below average openness and the car non-users being the least likely adopters. Furthermore, participants aged between 35 and 44 showed a significantly higher likelihood of subscription to the MaaS scheme as opposed to their younger (18-24 years) and older (55 years or above) counterparts. This result doesn't reflect the generally higher openness of the younger generations to using new mobility concepts like carsharing or ridesharing commonly found in other studies [35]. The only other demographic influence that has been found is the number of children in the household, where households with two or more children were significantly less likely to subscribe to MaaS than households with only one child or none. Building on this research, Ho et al. [21] conducted a similar stated choice analysis in Tyneside, UK comparing the new results to study previously done in Sydney. They find similar motives and barriers for the uptake of MaaS yet the actual adoption level strongly depends on local public transport and sharing offers. MaaS travel bundles customized to the travel needs would be key for adoption. Generally, MaaS plans including public transport are strongly preferred over plans with only sharing offers (e.g. bikesharing, carsharing) [30]. Availability of child seats, reliability and security were some of the reported caveats with carsharing within a MaaS bundle [30].

The above studies provide important insights into challenges with designing MaaS subscription plans, business models, socio-demographic characteristics of adopters and, to some extent, specific needs that would have to be fulfilled for higher acceptance rates. With this paper we add a differentiated view to the adoption intention by analysing the openness for MaaS for different trip purposes. We provide additional sociodemographic and psychological factors not yet studied in context of openness to use MaaS and test two potential levers to increase this openness. Last, we provide a thorough analysis of needs that could motivate the openness to MaaS for the different trip purposes in an openended design.

Based on the above experiments and results from scholars, a review of the literature and general insights obtained from technology diffusion, we hypothesize that the openness to use a combined mobility service for commuting, short weekday leisure trips and weekend leisure trips is significantly higher for the following groups:

H1) middle-aged (ages 35-54) participants as compared to younger (ages 18-34) and older (55 and above) participants;

H2) more educated participants, as they tend to exhibit a higher awareness of sustainable innovations and understanding of complex topics like MaaS [48]; and H3) infrequent car users (predominantly using public transport) as compared to very frequent car users (predominantly using a private car).

Based on the research of Fairley [15], Schlüter and Weyer [43] and Sovacool et al. [48], we further hypothesize that openness to using a combined mobility service for commuting, weekday leisure trips and weekend leisure trips is significantly higher for the following groups:

H4) participants that use carsharing (including peer-topeer carsharing) at least a few times a month compared to those that never use carsharing (thus having experience with carsharing);

H5) participants with pro-environmental attitudes since MaaS is thought to increase sustainability (by reducing car usage, congestion and emissions); and 
H6) participants with the intention to reduce car usage.

\subsection{Accelerating the uptake of innovations - two behavioural mechanisms}

In this section, two additional hypotheses related to mechanisms which can accelerate the uptake of innovation and, particularly, of MaaS are derived. These hypotheses have then been tested by means of two experiments. Due to the increasing role of media and other online information sites in shaping behavioural decisions, the first experiment includes the widely encountered peer effects via online ratings. The second experiment is based on providing information about future policy measures. Both experiments and their treatments are described in detail in section 3.1.

The term peer effect reflects the idea that one's own behaviour is moderated by the actions of others, be they family members, friends or complete strangers. A wide range of studies finds that peer influence is a strong determinant of social behaviour [36, 37, 39]. As such, framing social reference points is a way to provide information on and ultimately influence other people's behaviour [52]. Gaker et al. [16] set up an experiment with a job-and-housing scenario that set participants the task of deciding whether to buy a conventional car, a hybrid car or no car at all. One group of participants were told what other participants in the same experiment chose to do (and thereby set a reference point). The results show that the auto-purchasing decision was significantly adjusted and aligned to the decisions made by peers. Other forms of peer effects are increasingly magnified by online interaction and widespread access to the internet and social media. Customers increasingly rely on the internet for information as it greatly reduces the effort needed to obtain desired content. Especially within the tourism industry, positively framed reviews have been demonstrated to significantly increase intention to book. This effect was demonstrated to be even greater with the addition of positive numerical ratings [49]. Likewise, although targeting the transport sector, Rasouli and Timmermans [38] studied the effect of electric vehicle (EV) car reviews on the intention to buy an EV through a stated preferences survey. The results show that positive reviews increase the utility of the intention to buy an EV. Through this variety of studies, it becomes apparent that the influence of social media, especially through the effect of information about peer behaviour and reviews, should not be neglected when promoting sustainable alternatives to the car. Hence, we hypothesize that peer reviews and ratings could also positively affect the willingness to try MaaS solutions.

H7) Showing participants a hypothetical top rating (for example, five out of five stars) for a combined mobility service increases the likelihood of their being open to using a combined mobility service as compared to showing them a lower rating (four stars out of five).

Clear and transparent policy communication is generally regarded as key for industries and businesses to be able to adapt to a new policy environment [32, 44]. Early communication can help industries to plan investments cost-effectively [7]. A well-known example is communication by central banks with respect to their future/ planned monetary policies [26]. In contrast, the effect of policy announcements on individuals is not much explored. This is surprising because policies directly addressing consumers (product bans, restrictions in usage, etc.) are being discussed more and more often in the context of emission reductions regarding mobility and transportation. Hence, it may well be that through certain policy announcements, people would also reflect upon their proper mobility behaviour and change their attitude towards new products and services [51]. Particularly in light of future restrictions due to such policies, people may consider accepting or at least trying other transportation options where they would not face those restrictions. This leads to the following last hypothesis:

H8) the announcement of future policies directly affecting consumers increases the willingness to try MaaS solutions.

Table 1 provides an overview of all eight hypotheses.

\section{Methodology}

To examine these questions empirically, we developed a set of questions that were embedded in the larger online Swiss Household Energy Demand Survey (SHEDS). The

Table 1 Overview of hypotheses tested within this study Openness to use a combined mobility service for commuting, short weekday leisure trips and weekend leisure trips is significantly higher for the following groups:

H1: Middle-aged (ages 35-54) participants as compared to younger (ages 18-34) and older (55 and above) participants

H2: More educated participants

H3: Infrequent car users as compared to very frequent car users

H4: Participants that use carsharing (including peer-to-peer carsharing) at least a few times a month compared to those that never use carsharing

H5: Participants with pro-environmental attitudes

H6: Participants with the intention to reduce car usage

H7: Participants who were shown a hypothetical top rating (for example, five out of five stars) for a combined mobility service compared to showing them a lower rating (four stars out of five)

H8: Participants who receive an announcement of future decided policies directly affecting them 
SHEDS is a sequential choice and socio-demographic as well as attitudinal questionnaire that started in 2016. It addresses the energy-related behaviour of Swiss citizens in the three fields of heating, electricity and mobility, providing insights into longitudinal changes and energy consumption reduction potential. The respondents are chosen randomly, with approximately 5500 participants per year (wave). More details about the design of the SHEDS can be retrieved in Weber et al. [54]. Overall, 5' 514 household individuals took part in the SHEDS 2018 wave, while 995 respondents were assigned to this paper's experimental study. In order to test $\mathrm{H} 7$ and $\mathrm{H} 8$ (peer and policy effects), two treatments for each hypothesis (each treatment receiving a different set of information) were prepared. Among the 995 respondents, 288 subjects were selected randomly to receive the peer and policy effect treatments, respectively.

Figure 1 represents the overall experimental setup, which also addressed other aspects not investigated in this paper. The introductory questions collected information about demographics, mobility behaviour and psychology. The 995 participants were then split into the two peer effect treatments T1 and T2 $(n=70$ each), policy treatments T3 and T4 ( $n=74$ each) and the control group comprising the remaining 707 respondents. The core exercise of the experiment was to choose a vehicle (private car) from a list of cars with different engine types (traditional fuel combustion, hybrid, electric) and indicate how often they would use the vehicle for the different types of trips (for commuting, weekday leisure trips (less than $10 \mathrm{~km}$ from place of residence) and weekend leisure trips). At the end of the experiment, the respondents were asked to state whether they would be open to using a combined mobility service for the three types of trips and had to answer some additional questions about MaaS. An informational text was shown to all participants explaining the term combined mobility to mitigate erroneous understandings.

\subsection{Description of treatments}

In order to simulate the effect of peer assessment, a fivestar rating, frequently used in various rating systems, was applied. After reading the general informational text about "combined mobility", the participants were told that a survey about a number of different sharing systems in Switzerland had been conducted, resulting in a satisfactory rating. In the first treatment (T1), four sharing systems, namely public transport, carsharing, car with driver (e.g. taxi, Uber) and a combined mobility service were given a rating of three or four stars. In the second treatment (T2), all modes received the same rating as in T1 except the combined mobility service, which was changed from four to five stars (see Appendix 1) in order to enforce a stronger sense of satisfaction.

The policy treatment (T3 and T4) is designed as an informational text that is shown before the core part of the experiment. Participants are informed about the greenhouse gas emission intensity of the transportation sector and about the international climate targets agreed in Paris 2015. Following that, they are informed about emissions in transportation in Switzerland and Swiss emission reduction targets. Then, they are presented with different policies in other countries directly addressing consumers, such as fossil-powered vehicle bans in city centres. Finally, they are informed that the Swiss government has set an EV quota to be reached by 2023. In T3, the specific policy measures to achieve the target are not yet defined, while in T4, measures are defined with implementation starting in 2021. In T3, consumers are thus only informed about potential consumer-addressing policies, while in $\mathrm{T} 4$, they have to expect their implementation in the near future. The exact wording can be found in Appendix 2.

\subsection{Overview of parameters and experimental study}

The sample consisted of roughly $52 \%$ male participants, with $51 \%$ living in the city, $28 \%$ in agglomerations and $21 \%$ in the countryside. More than $50 \%$ hold a higher

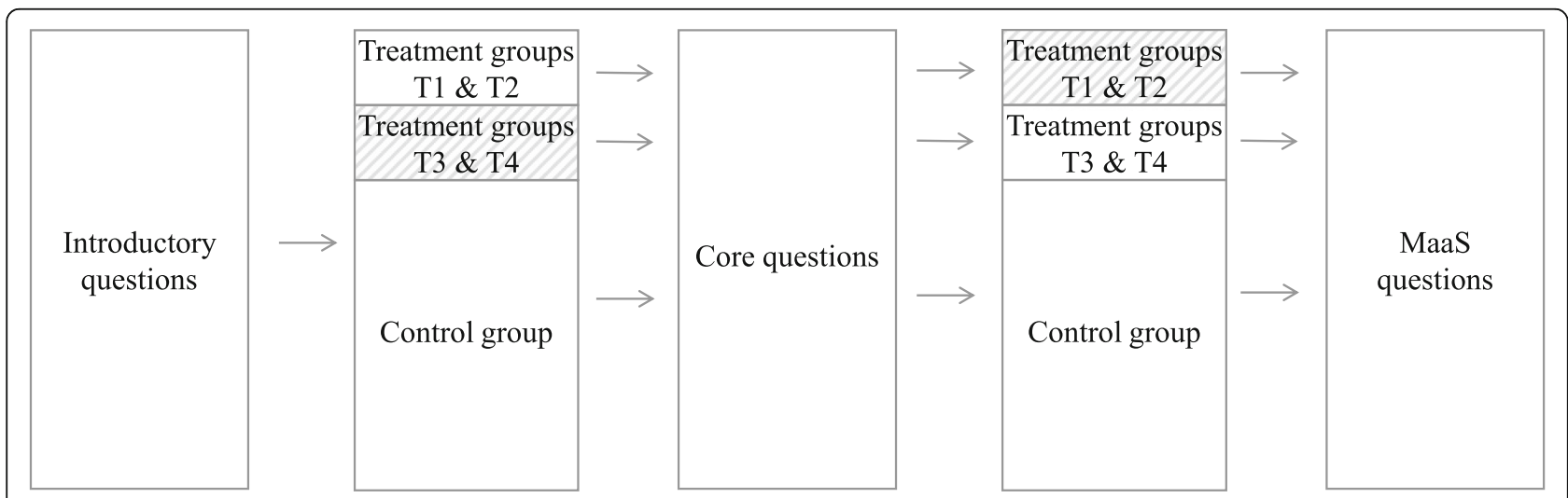

Fig. 1 Experimental setup. The treatment blocks with diagonal shading represent the time point of applying the treatment 
education degree (university, university of applied sciences or higher vocational school), $13.5 \%$ a high school diploma and $32.7 \%$ an apprenticeship. The sample has a medium gross monthly income range of $6^{\prime} 000-8^{\prime} 999$ CHF (30.1\%). On average, there are two participants (2.25) per household, and the average age is 49 years. Comparing the study sample with the overall SHEDS sample, we see that we have an overrepresentation of men and a slightly older sample. Other characteristics, such as place of residence, education and household income do not differ significantly. The SHEDS 2018 sample is representative for the German-speaking and French-speaking populations of Switzerland for the variables gender, age, language distribution and residential ownership/tenant status (see Table 2). On the other hand, the education level is significantly higher than the overall Swiss population $\left(\mathrm{x}^{2}(2, N=\right.$ $890)=34.4, p<0.001$ ).

The variables of interest (dependent variables: DVs) are openness to using a combined mobility service for commuting, weekday leisure trips and weekend leisure trips, coded as a binary response variable (yes/no). In order to test the hypotheses advanced earlier, we used a binary logistic regression model. Therefore, we tested the variables listed in Table 3 (independent variables: IVs) to see whether they have a significant influence on the outcome of the DV. If the answer to the DV was "no", we posed an open-format question asking the respondent to state the characteristics that a combined mobility service would need to have to be able to persuade him/her to use the service for the specific trip purpose (commuting, weekday leisure trips, weekend leisure trips). Each answer was grouped into one of 16 categories depicting common themes and meanings to facilitate the evaluation process. For the analysis of questions related to commuting (both binary logistic regression as well as analysis of open-format questions), we excluded retired participants as they often do not work anymore.

We included common demographics such as age, gender, place of residence and income in the study. Together with the type of public transport tickets and time from home to work/leisure/weekend destinations, they ensure that the regression results are not confounded by these variables. To investigate hypotheses $\mathrm{H} 1$ to $\mathrm{H} 6$, we included (from the variables available in SHEDS) education, mode choice, carsharing frequency, pro-environmental attitudes and plans to reduce car usage, as described in Table 3 . The variable plans to reduce car usage was obtained through a Likert scale from 1 , very unlikely, to 5 , very likely,

Table 2 Representativeness of study sample

\begin{tabular}{|c|c|c|c|c|}
\hline & $\begin{array}{l}\text { Study } \\
(\boldsymbol{n}=995)\end{array}$ & $\begin{array}{l}\text { SHEDS } 2018 \\
\left(\boldsymbol{n}=5^{\prime} 514\right)\end{array}$ & Difference Study/SHEDS & Swiss population \\
\hline \multicolumn{5}{|l|}{ Age } \\
\hline Average & 48.65 & 44.25 & $t(994)=9.20, p=<0.001$ & \\
\hline \multicolumn{5}{|l|}{ Gender } \\
\hline Male & $51.5 \%$ & $47.3 \%$ & $X^{2}(1, N=995)=6.90, p=0.009$ & $49.6 \%^{\mathrm{a}}$ \\
\hline Female & $48.5 \%$ & $52.7 \%$ & & $50.4 \%^{\mathrm{a}}$ \\
\hline \multicolumn{5}{|l|}{ Education } \\
\hline Apprenticeship & $32.7 \%$ & $33.3 \%$ & $X^{2}(2, N=890)=0.19, p=0.91$ & $41.1 \%^{\mathrm{b}}$ \\
\hline High school & $13.5 \%$ & $13.6 \%$ & & $9.4 \%^{\mathrm{b}}$ \\
\hline Higher education & $53.8 \%$ & $53.1 \%$ & & $49.5 \%^{\mathrm{b}}$ \\
\hline \multicolumn{5}{|l|}{ Place of residence } \\
\hline City & $50.9 \%$ & $50.1 \%$ & $X^{2}(2, N=995)=1.13, p=0.57$ & \\
\hline Agglomeration & $28.3 \%$ & $27.7 \%$ & & \\
\hline Countryside & $20.8 \%$ & $22.2 \%$ & & \\
\hline \multicolumn{5}{|l|}{ Gross Household income } \\
\hline Less than 3'000 CHF & $4.1 \%$ & $6.0 \%$ & $x^{2}(5, N=845)=7.60, p=0.18$ & $10^{\prime} 033 \mathrm{CHF}^{\mathrm{c}}$ (average) \\
\hline $3^{\prime} 000-4^{\prime} 500 \mathrm{CHF}$ & $10.3 \%$ & $10.0 \%$ & & \\
\hline $4^{\prime} 501-6^{\prime} 000 \mathrm{CHF}$ & $18.9 \%$ & $17.9 \%$ & & \\
\hline $6^{\prime} 001-9^{\prime} 000$ CHF & $30.1 \%$ & $28.9 \%$ & & \\
\hline $9^{\prime} 001-12^{\prime} 000$ CHF & $21.9 \%$ & $20.9 \%$ & & \\
\hline More than $12^{\prime} 000 \mathrm{CHF}$ & $14.7 \%$ & $16.3 \%$ & & \\
\hline
\end{tabular}

${ }^{\mathrm{a}}[9] ;{ }^{\mathrm{b}}[10]{ }^{\mathrm{c}}[8]$ 
Table 3 Sample characteristics $(n=995)$

\begin{tabular}{|c|c|c|}
\hline Items & Categories & Distribution \\
\hline \multicolumn{3}{|l|}{ Dependent Variable (DV) } \\
\hline \multirow{2}{*}{$\begin{array}{l}\text { Openness to using a } \\
\text { combined mobility } \\
\text { service for commuting }\end{array}$} & No & $62.0 \%$ \\
\hline & Yes & $38.0 \%$ \\
\hline \multirow{2}{*}{$\begin{array}{l}\text { Openness to using a } \\
\text { combined mobility } \\
\text { service for weekday } \\
\text { leisure trips }\end{array}$} & No & $52.6 \%$ \\
\hline & Yes & $47.4 \%$ \\
\hline \multirow{2}{*}{$\begin{array}{l}\text { Openness to using a } \\
\text { combined mobility } \\
\text { service for weekend trips }\end{array}$} & No & $46.1 \%$ \\
\hline & Yes & $53.9 \%$ \\
\hline \multicolumn{3}{|l|}{ Treatment (IV) } \\
\hline \multirow[t]{5}{*}{ Policy and peer effects ${ }^{a}$} & Control & $71.1 \%$ \\
\hline & 4-star review (T1) & $7.0 \%$ \\
\hline & 5-star review (T2) & $7.0 \%$ \\
\hline & No policy yet (T3) & $7.4 \%$ \\
\hline & Policy decided (T4) & $7.4 \%$ \\
\hline \multicolumn{3}{|l|}{ Socio-Demographics (IV) } \\
\hline $\mathrm{Age}^{\mathrm{c}}$ & Average (standard deviation) & $\begin{array}{l}48.65 \\
(15.09)\end{array}$ \\
\hline \multirow[t]{3}{*}{ Age group ${ }^{a}$} & $18-34$ years & $24 \%$ \\
\hline & $35-54$ years & $40.8 \%$ \\
\hline & More than 55 years & $35.2 \%$ \\
\hline \multirow[t]{2}{*}{ Gender $^{\mathrm{b}}$} & Male & $51.5 \%$ \\
\hline & Female & $48.5 \%$ \\
\hline \multirow[t]{3}{*}{ Education $^{a}$} & Apprenticeship & $32.7 \%$ \\
\hline & High school & $13.5 \%$ \\
\hline & Higher education & $53.8 \%$ \\
\hline \multirow[t]{3}{*}{ Place of residence ${ }^{b}$} & City & $50.9 \%$ \\
\hline & Agglomeration & $28.3 \%$ \\
\hline & Countryside & $20.8 \%$ \\
\hline \multirow[t]{6}{*}{ Household income $^{b}$} & Less than $3^{\prime} 000 \mathrm{CHF}$ & $4.1 \%$ \\
\hline & $3^{\prime} 000-4^{\prime} 500 \mathrm{CHF}$ & $10.3 \%$ \\
\hline & 4'501-6'000 CHF & $18.9 \%$ \\
\hline & $6^{\prime} 001-9^{\prime} 000 \mathrm{CHF}$ & $30.1 \%$ \\
\hline & $9^{\prime} 001-12^{\prime} 000$ CHF & $21.9 \%$ \\
\hline & More than $12^{\prime} 000 \mathrm{CHF}$ & $14.7 \%$ \\
\hline \multicolumn{3}{|l|}{ Mobility behaviour (IV) } \\
\hline \multirow{5}{*}{$\begin{array}{l}\text { Dominant mode choice: } \\
\text { commuting }^{a}\end{array}$} & Private car & $33.7 \%$ \\
\hline & Public transportation & $42.1 \%$ \\
\hline & Soft mobility (bike, foot) & $17.1 \%$ \\
\hline & Multimodal mobility & $1.4 \%$ \\
\hline & Does not work & $5.7 \%$ \\
\hline \multirow{4}{*}{$\begin{array}{l}\text { Dominant mode choice: } \\
\text { leisure }^{a}\end{array}$} & Private car & $47.5 \%$ \\
\hline & Public transportation & $29.1 \%$ \\
\hline & Soft mobility (bike, foot) & $20.1 \%$ \\
\hline & Multimodal mobility & $3.3 \%$ \\
\hline
\end{tabular}

Table 3 Sample characteristics $(n=995)$ (Continued)

\begin{tabular}{|c|c|c|}
\hline Items & Categories & Distribution \\
\hline \multirow[t]{5}{*}{ Mobility sharing: $\mathrm{car}^{\mathrm{a}}$} & Never & $61.1 \%$ \\
\hline & Every few months & $22.6 \%$ \\
\hline & Once a month & $9.1 \%$ \\
\hline & One a week & $4.4 \%$ \\
\hline & Several times a week & $2.7 \%$ \\
\hline \multirow{4}{*}{$\begin{array}{l}\text { Type of public transport } \\
\text { pass }^{\text {b }}\end{array}$} & GA travel card 1st class & $4.3 \%$ \\
\hline & GA travel card 2nd class & $19.4 \%$ \\
\hline & Regional pass & $21.3 \%$ \\
\hline & None & $55.0 \%$ \\
\hline $\begin{array}{l}\text { Time used for commuting } \\
\text { home-work (min) }\end{array}$ & $\begin{array}{l}\text { Average (standard } \\
\text { deviation) }\end{array}$ & $\begin{array}{l}29.26 \\
(25.89)\end{array}$ \\
\hline $\begin{array}{l}\text { Time used for commuting } \\
\text { home-leisure activity } \\
\text { (min) }\end{array}$ & Average (standard deviation) & $\begin{array}{l}17.56 \\
(20.62)\end{array}$ \\
\hline $\begin{array}{l}\text { Time used for commuting } \\
\text { home-weekend trip } \\
\text { (min) }\end{array}$ & Average (standard deviation) & $\begin{array}{l}50.59 \\
(57.00)\end{array}$ \\
\hline \multirow{6}{*}{$\begin{array}{l}\text { Importance of mobility } \\
\text { service attributes (Mean } \\
\text { (standard deviation) from } \\
\text { Likert scale: } 1 \text {, not at all } \\
\text { important, to 5, extremely } \\
\text { important) })^{c}\end{array}$} & $\begin{array}{l}\text { Availability of all possible } \\
\text { options }\end{array}$ & $3.09(1.31)$ \\
\hline & Cheap price & $3.55(1.16)$ \\
\hline & Intuitive and easy to use & $3.76(1.19)$ \\
\hline & $\begin{array}{l}\text { Route with lowest } \mathrm{CO}_{2} \\
\text { emissions }\end{array}$ & $2.84(1.24)$ \\
\hline & Find fastest possible route & $3.52(1.21)$ \\
\hline & Waiting time $<30 \mathrm{~min}$ & $3.65(1.26)$ \\
\hline \multicolumn{3}{|l|}{ Psychology (IV) } \\
\hline $\begin{array}{l}\text { Pro-environmental } \\
\text { attitudes }^{\mathrm{a}}\end{array}$ & $\begin{array}{l}\text { Mean Likert scale (1, totally } \\
\text { disagree to } 5 \text {, totally agree) } \\
\text { from } 12 \text { items }\end{array}$ & $3.66(0.75)$ \\
\hline $\begin{array}{l}\text { Plans to reduce car } \\
\text { usage }^{a}\end{array}$ & $\begin{array}{l}\text { Likert scale (1, very unlikely, } \\
\text { to } 5 \text {, very likely) }\end{array}$ & $2.58(1.22)$ \\
\hline
\end{tabular}

while the pro-environmental attitudes were calculated as the mean of 12 questions with a range from 1, totally disagree, to 5 , totally agree. Details on the description of the 12 pro-environmental questions can be found in Appendix 3.

\subsection{Statistical analysis}

To decide which IVs to include in the model, we followed four basic steps. First, continuous variables were checked for outliers and extreme values. Second, we checked for multicollinearity among explanatory variables through a correlation matrix and the inspection of the variance inflation factor (VIF). No correlations above $r=0.6$ were detected nor were any VIF higher than 2.5. We thus reason that multicollinearity is not an issue in our study [2]. Third, the assumption of linear relationships, that is, linearity of logit, 
has been tested using the model fit statistics (Hosmer-Lemeshow test). Fourth and last, all variables and their two-way interactions were included in the model. In a stepwise procedure, each interaction was removed from the model if the $p$-value was above 0.05 . Also, individual regression parameters were excluded from the model if they didn't improve the model significantly (i.e. model fit or pseudo $R^{2}$ ). No two-way interactions remained significant. Subsequently, we used the Wald chi-square statistic (Wald $\left.X^{2}\right)$ to test the statistical significance of each regression parameter. Furthermore, we accounted for the accumulation of type 1 errors (rejecting the null hypothesis when it is actually true) by using the Bonferroni-Holm method. This is necessary when testing several hypotheses with one model. The Bonferroni-Holm method is slightly less conservative than the Bonferroni correction yet also increases the possibility of finding real effects [1]. The final set of variables included for each DV is shown in the next section.

\section{Results}

Overall, $53.9 \%$ of participants declared being open to using a combined mobility service for weekend leisure trips, which was significantly more open than for using it for weekday leisure trips (47.4\%), $\chi^{2} \quad(1, N=995)=$ $16.5, p<0.001$, or commuting (38.0\%), $\mathrm{X}^{2}(1, N=995)=$ 106.5, $p<0.001$. The following section describes factors that could increase this openness for all three trip purposes.

\subsection{Binary logistic regression}

In order to test the hypotheses pertaining to the demographical ( $\mathrm{H} 1$ and $\mathrm{H} 2)$, mobility-related $(\mathrm{H} 3$ and $\mathrm{H} 4)$ as well as psychological factors (H5 and H6) described in Section 2.1 and the treatments mentioned in Section 2.2 (H7 and H8), we conducted a binary logistic regression model for commuting, weekday leisure trips and weekend leisure trips (Table 4). The Hosmer-Lemeshow test was non-significant for all models, indicating that the models show good fit to the data. Additionally, the Wald chi-square statistic signals the significance of the effect for each variable, whereas the $\operatorname{Exp}(\mathrm{B})$ reflects the odds ratio and CI stands for the confidence interval of the odds ratio. The reference category of each variable is written in parentheses.

Odds ratios are defined as the likelihood of an outcome occurring for one category of a variable versus the outcome occurring for the reference category of the same variable. For example, a public transport user has a 2.4 higher likelihood of being open to using a combined mobility service for commuting than does a private car user. If the variable is continuous, which is the case for "plans to reduce car usage", the odds ratio indicates the increase in likelihood of being open to using a combined mobility service for commuting for a one-point increase of the continuous variable (in this case, it would be one point on the Likert scale).

The decisive variables for openness to MaaS services vary among commuting, weekday leisure trips and weekend leisure trips. Only the use of public transport (H3) significantly increases the likelihood of being open to MaaS in all three scenarios. Thus, we can be confident in not rejecting H3 (predominantly use public transport). The hypotheses H1 (middle aged), H2 (higher education), H4 (experience with carsharing), H5 (pro-environmental attitudes) and H6 (intention to reduce car usage) cannot be supported for all scenarios. For weekday and weekend leisure trips, a higher education degree $(\mathrm{H} 2)$ and using carsharing at least every few months (H4) positively influence openness. For weekend leisure trips, the age group of 35-54 (H1) and proenvironmental attitudes (H5) also positively influence openness. For commuting, on the other hand, plans to reduce car usage (H6) significantly increase the likelihood of being open to using a combined mobility service.

The peer effects treatments (T1 and T2) and the undecided policy treatment (T3) have no significant effect on openness to such services. On the other hand, T4 is significant at the $5 \%$ level for weekday and weekend leisure trips. Participants who were informed about future policies and a fixed implementation plan of measures that would affect their usage were thus more likely to be open to a combined mobility service. We would therefore not reject hypothesis $\mathrm{H} 8$ for weekday and weekend leisure trips.

\subsection{The ideal characteristics of a combined mobility service}

Sixty-two per cent of the "commuting" group, 53\% of the "weekday leisure" group and $46 \%$ of the "weekend leisure" group were unwilling to use a combined mobility service for commuting, weekday leisure trips and weekend leisure trips, respectively (refer to Table 3). To better understand the reasons and needs that would motivate them to use such a service, we posed an open-format question. The respondents were asked to specify what characteristics such a combined service would need to have in order to make them willing to use it for the said purpose (either commuting, weekday leisure trips or weekend leisure trips). The results are shown in Fig. 2, in which, from the answer totals of 369 
Table 4 Results of the binary logistic regression

\begin{tabular}{|c|c|c|c|c|c|c|}
\hline & \multirow{2}{*}{$\begin{array}{l}\text { Treatments/ } \\
\text { Hypotheses }\end{array}$} & \multirow{2}{*}{$\begin{array}{l}\text { Wald } \\
x^{2}\end{array}$} & \multirow[t]{2}{*}{$P$-value } & \multirow[t]{2}{*}{$\operatorname{Exp}(B)$} & \multicolumn{2}{|c|}{ 95\% Cl for $\operatorname{Exp}(B)$} \\
\hline & & & & & Lower & Upper \\
\hline \multicolumn{7}{|c|}{ Commuting (Nagelkerke $\mathrm{R}^{2}=12.9 \%$ ) } \\
\hline Treatment (control) & & 2.863 & 0.581 & & & \\
\hline 4 stars & $\mathrm{T} 1$ & 0.044 & 0.834 & 1.067 & 0.581 & 1.961 \\
\hline 5 stars & $\mathrm{T} 2(\mathrm{H} 7)$ & 1.559 & 0.212 & 0.642 & 0.320 & 1.287 \\
\hline Policy planned & T3 & 0.077 & 0.781 & 1.096 & 0.575 & 2.086 \\
\hline Policy decided & $\mathrm{T} 4(\mathrm{H} 8)$ & 0.928 & 0.335 & 1.338 & 0.740 & 2.420 \\
\hline Age group (55+) & & 6.409 & 0.041 & & & \\
\hline $18-34$ & & 4.386 & 0.036 & 1.680 & 1.034 & 2.730 \\
\hline $35-54$ & $\mathrm{H} 1$ & 0.125 & 0.723 & 1.083 & 0.696 & 1.685 \\
\hline Gender (Male) & & 0.163 & 0.686 & 0.934 & 0.669 & 1.302 \\
\hline Education (Apprenticeship) & & 1.344 & 0.511 & & & \\
\hline High school & & 0.502 & 0.479 & 1.223 & 0.701 & 2.135 \\
\hline Higher education & $\mathrm{H} 2$ & 1.317 & 0.251 & 1.258 & 0.850 & 1.861 \\
\hline Place of residence (City) & & 3.921 & 0.141 & & & \\
\hline Agglomeration & & 3.549 & 0.060 & 1.478 & 0.984 & 2.219 \\
\hline Countryside & & 1.583 & 0.208 & 1.325 & 0.855 & 2.055 \\
\hline Household income (CHF) & & 2.369 & 0.124 & 1.048 & 0.987 & 1.113 \\
\hline Mode choice (Private car) & & 12.528 & 0.014 & & & \\
\hline Public transport & H3 & 8.924 & $0.003^{* *}$ & 2.358 & 1.343 & 4.141 \\
\hline Soft mobility (bike, foot) & & 1.099 & 0.294 & 1.318 & 0.787 & 2.208 \\
\hline Multimodal mobility & & 2.471 & 0.116 & 2.772 & 0.778 & 9.881 \\
\hline Does not work & & 0.913 & 0.339 & 0.632 & 0.247 & 1.620 \\
\hline Mobility sharing: Car (Never) & $\mathrm{H} 4$ & 8.829 & 0.066 & & & \\
\hline Every few months & & 1.285 & 0.257 & 1.257 & 0.846 & 1.868 \\
\hline Once a month & & 2.833 & 0.092 & 1.586 & 0.927 & 2.713 \\
\hline Once a week & & 2.305 & 0.129 & 0.524 & 0.227 & 1.207 \\
\hline Several times a week & & 2.747 & 0.097 & 2.110 & 0.873 & 5.100 \\
\hline Public transport passes (None) & & 8.388 & 0.039 & & & \\
\hline GA 1st class & & 0.230 & 0.632 & 1.241 & 0.513 & 3.007 \\
\hline GA 2nd class & & 6.244 & 0.012 & 0.488 & 0.278 & 0.857 \\
\hline Regional pass & & 1.665 & 0.197 & 0.697 & 0.402 & 1.206 \\
\hline Time home-work (min) & & 1.978 & 0.160 & 1.005 & 0.998 & 1.012 \\
\hline Pro-environmental attitude & H5 & 1.085 & 0.298 & 1.128 & 0.899 & 1.415 \\
\hline Plans to reduce car usage & $\mathrm{H} 6$ & 8.592 & $0.003^{* *}$ & 1.227 & 1.070 & 1.407 \\
\hline Constant & & 6.919 & 0.009 & 0.171 & & \\
\hline \multicolumn{7}{|c|}{ Weekday leisure trips (Nagelkerke $R^{2}=14.1 \%$ ) } \\
\hline Treatment (control) & & 9.404 & 0.052 & & & \\
\hline 4 stars, $\mathrm{T} 1$ & $\mathrm{~T} 1$ & 0.618 & 0.432 & 1.243 & 0.723 & 2.136 \\
\hline 5 stars, $\mathrm{T} 2$ & $\mathrm{~T} 2(\mathrm{H} 7)$ & 0.271 & 0.603 & 1.166 & 0.654 & 2.081 \\
\hline Policy planned, T3 & T3 & 0.381 & 0.537 & 1.192 & 0.683 & 2.080 \\
\hline
\end{tabular}


Table 4 Results of the binary logistic regression (Continued)

\begin{tabular}{|c|c|c|c|c|c|c|}
\hline & \multirow{2}{*}{$\begin{array}{l}\text { Treatments/ } \\
\text { Hypotheses }\end{array}$} & \multirow{2}{*}{$\begin{array}{l}\text { Wald } \\
x^{2}\end{array}$} & \multirow[t]{2}{*}{$P$-value } & \multirow[t]{2}{*}{$\operatorname{Exp}(B)$} & \multicolumn{2}{|c|}{$95 \% \mathrm{Cl}$ for $\operatorname{Exp}(\mathrm{B})$} \\
\hline & & & & & Lower & Upper \\
\hline Policy decided, T4 & $\mathrm{T} 4$ (H8) & 9.034 & $0.003^{* *}$ & 2.321 & 1.340 & 4.019 \\
\hline Age group (55+) & & 3.332 & 0.189 & & & \\
\hline $18-34$ & & 3.053 & 0.081 & 1.423 & 0.958 & 2.114 \\
\hline $35-54$ & $\mathrm{H} 1$ & 1.763 & 0.184 & 1.254 & 0.898 & 1.752 \\
\hline Gender (Male) & & 0.001 & 0.972 & 1.005 & 0.751 & 1.345 \\
\hline Education (Apprenticeship) & & 10.474 & 0.005 & & & \\
\hline High school & & 0.141 & 0.707 & 1.094 & 0.684 & 1.749 \\
\hline Higher education & $\mathrm{H} 2$ & 9.208 & $0.002^{* *}$ & 1.675 & 1.200 & 2.337 \\
\hline Place of residence (City) & & 0.181 & 0.914 & & & \\
\hline Agglomeration & & 0.160 & 0.689 & 0.933 & 0.662 & 1.313 \\
\hline Countryside & & 0.075 & 0.784 & 0.947 & 0.642 & 1.397 \\
\hline Household income (CHF) & & 4.943 & 0.026 & 1.062 & 1.007 & 1.119 \\
\hline Mode choice (Private car) & & 10.522 & 0.015 & & & \\
\hline Public transport & H3 & 7.804 & $0.005^{* *}$ & 1.666 & 1.165 & 2.384 \\
\hline Soft mobility (bike, foot) & & 0.018 & 0.894 & 1.026 & 0.699 & 1.508 \\
\hline Multimodal mobility & & 2.858 & 0.091 & 1.985 & 0.896 & 4.396 \\
\hline Mobility sharing: Car (Never) & & 22.260 & 0.000 & & & \\
\hline Every few months & $\mathrm{H} 4$ & 13.453 & $0.000 * * *$ & 1.936 & 1.360 & 2.755 \\
\hline Once a month & & 13.252 & 0.000 & 2.616 & 1.559 & 4.389 \\
\hline Once a week & & 0.340 & 0.560 & 1.234 & 0.609 & 2.501 \\
\hline Several times a week & & 0.308 & 0.579 & 1.287 & 0.528 & 3.138 \\
\hline Pro-environmental attitude & $\mathrm{H} 5$ & 4.712 & 0.030 & 1.247 & 1.022 & 1.522 \\
\hline Plans to reduce car usage & $\mathrm{H} 6$ & 2.559 & 0.110 & 1.103 & 0.978 & 1.244 \\
\hline Constant & & 28.554 & 0.000 & 0.098 & & \\
\hline \multicolumn{7}{|c|}{ Weekend leisure trips (Nagelkerke $R^{2}=19.9 \%$ ) } \\
\hline Treatment (control) & & 6.908 & 0.141 & & & \\
\hline 4 stars & $\mathrm{T} 1$ & 0.670 & 0.413 & 1.264 & 0.721 & 2.214 \\
\hline 5 stars & $\mathrm{T} 2(\mathrm{H} 7)$ & 0.045 & 0.832 & 1.068 & 0.583 & 1.955 \\
\hline Policy planned & T3 & 0.217 & 0.642 & 1.146 & 0.645 & 2.038 \\
\hline Policy decided & $\mathrm{T} 4(\mathrm{H} 8)$ & 6.538 & $0.011^{* *}$ & 2.124 & 1.192 & 3.785 \\
\hline Age group (55+) & & 6.454 & 0.040 & & & \\
\hline $18-34$ & & 4.468 & 0.035 & 1.555 & 1.033 & 2.343 \\
\hline $35-54$ & $\mathrm{H} 1$ & 5.071 & $0.024^{*}$ & 1.480 & 1.052 & 2.082 \\
\hline Gender (Male) & & 0.007 & 0.933 & 1.013 & 0.750 & 1.367 \\
\hline Education (Apprenticeship) & & 12.899 & 0.002 & & & \\
\hline High school & & 0.004 & 0.951 & 1.015 & 0.632 & 1.630 \\
\hline Higher education & $\mathrm{H} 2$ & 10.590 & $0.001^{* * *}$ & 1.752 & 1.250 & 2.456 \\
\hline Place of residence (City) & & 5.857 & 0.053 & & & \\
\hline Agglomeration & & 3.712 & 0.054 & 0.710 & 0.501 & 1.006 \\
\hline Countryside & & 4.212 & 0.040 & 0.661 & 0.445 & 0.982 \\
\hline Household income (CHF) & & 4.269 & 0.039 & 1.058 & 1.003 & 1.116 \\
\hline Mode choice (Private car) & & 17.979 & 0.000 & & & \\
\hline
\end{tabular}


Table 4 Results of the binary logistic regression (Continued)

\begin{tabular}{|c|c|c|c|c|c|c|}
\hline & \multirow{2}{*}{$\begin{array}{l}\text { Treatments/ } \\
\text { Hypotheses }\end{array}$} & \multirow{2}{*}{$\begin{array}{l}\text { Wald } \\
x^{2}\end{array}$} & \multirow[t]{2}{*}{$P$-value } & \multirow[t]{2}{*}{$\operatorname{Exp}(B)$} & \multicolumn{2}{|c|}{ 95\% Cl for $\operatorname{Exp}(\mathrm{B})$} \\
\hline & & & & & Lower & Upper \\
\hline Public transport & H3 & 12.384 & $0.000^{* * *}$ & 1.936 & 1.340 & 2.798 \\
\hline Soft mobility (bike, foot) & & 3.368 & 0.066 & 1.442 & 0.975 & 2.133 \\
\hline Multimodal mobility & & 7.987 & 0.005 & 3.732 & 1.497 & 9.301 \\
\hline Mobility sharing: Car (Never) & & 26.240 & 0.000 & & & \\
\hline Every few months & $\mathrm{H} 4$ & 22.425 & $0.000^{* * *}$ & 2.483 & 1.704 & 3.618 \\
\hline Once a month & & 7.106 & 0.008 & 2.063 & 1.211 & 3.514 \\
\hline Once a week & & 1.922 & 0.166 & 1.676 & 0.808 & 3.479 \\
\hline Several times a week & & 0.214 & 0.643 & 1.240 & 0.499 & 3.085 \\
\hline Pro-environmental attitude & H5 & 7.984 & $0.005^{* *}$ & 1.344 & 1.095 & 1.649 \\
\hline Plans to reduce car usage & $\mathrm{H} 6$ & 2.956 & 0.086 & 1.116 & 0.985 & 1.265 \\
\hline Constant & & 29.586 & 0.000 & 0.089 & & \\
\hline
\end{tabular}

(commuting), 404 (weekday leisure) and 346 (weekend trip), those related to being more ecological, usable without a smartphone, more comfortable, usable without a driving licence, wheelchair accessible and promoting active mobility were mentioned too few (fewer than 10) times and were thus excluded from Fig. 2. On the other hand, Fig. 3 depicts those participants that either do not see the necessity of a combined mobility service or just cannot be motivated to use one. The answers provide insights into the specific needs of the society concerning this new mobility service, thus supporting decision-makers and transport planners in the design and implementation of related proposals.

\section{Discussion and limitations}

With the present study, we are able to discuss factors influencing openness to combined mobility services. It has to be noted that the results do not give a clearcut interpretation of the decisive variables. The nonrejection of $\mathrm{H} 3$ may be interpreted as $\mathrm{MaaS}$ being perceived as an addition to current public transportation offers rather than an overall new mobility concept, which is in line with public transport users being more open to it. Similar to Ho et al. [20], we find that participants over 35 and under 55 years old are more open, in contrast to multiple studies on general innovation diffusion. A higher education degree, using carsharing at least every few months, the intention to reduce car usage and pro-environmental behaviour also seem to partly influence openness to MaaS. Interestingly, the higher the level of carsharing use, the less significant were the results (here, sharing refers to both general peer-to-peer sharing through family or friends as well as company-based carsharing). This might be explained by the very few participants that actually use carsharing once a week $(4.4 \%, n=36)$ or several times a week $(2.7 \%, n=23)$; thus, the sample size might be too small for a significant effect. An alternative explanation could be that people that already use carsharing very frequently do not need a MaaS platform to use a specific service they are already very accustomed to. One of the core expectations of MaaS is that it may reduce the use of private cars. It is thus promising that those who aim to reduce their car usage are more open to using MaaS in their daily commute as they might perceive $\mathrm{MaaS}$ as a suitable alternative [50]. The reasons that the intention to reduce one's own car usage is not significant for weekday and weekend leisure trips might stem from the fact that congestion levels are highest during commuting [6] and thus negatively influence the satisfaction level of travel and, in turn, increase the intention to reduce car usage in commuting, although not for leisure trips, during which congestion is less prevalent [56].

The significantly higher probability of choosing MaaS solutions following T4 but not T3 supports the hypotheses that people would take into account policy announcements directly addressing them as consumers. The clear announcement of implementation plans for policy measures may represent a promising lever to reduce the emissions of the transportation sector by influencing openness to changing mobility behaviour. Nevertheless, the variable is only significant for weekday and weekend leisure trips. One reason may be that people (who do not want to reduce their car usage, as discussed above) do not see any suitable alternative to the car with respect to commuting and are thus less willing to change their current routine [12]; however, this has to be analysed in future research. A promising 


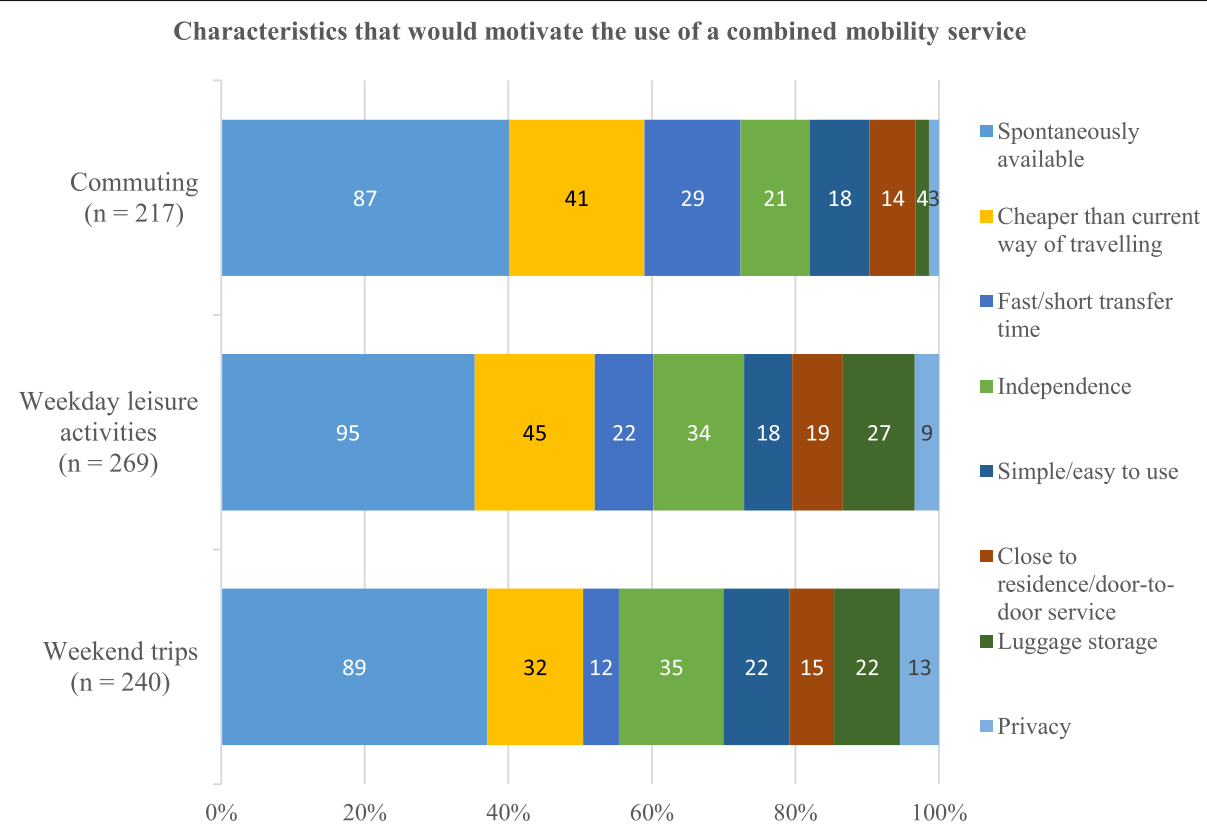

Fig. 2 Characteristics that would motivate the use of a combined mobility service for commuting, weekday leisure and weekend leisure trips

alternative might be vanpools integrated into MaaS, as Ditmore and Deming [14] report consequently reduced commuter stress levels.

The peer effect treatment of a better rating for a combined service (T2) did not increase openness to using such a service and therefore cannot provide confirmation of previous findings of scholars [38]. However, the present work only includes ratings without reviews. The influence of ratings could be amplified when shown together with reviews [49]. Furthermore, the difference between already positively framed ratings of four to five stars might be perceived as too small to have a significant effect. Especially with a small sample size of $n=74$, finding a significant effect is difficult. Last, when lacking personal experience with such a service, hypothetical ratings may be perceived as less trustworthy and therefore hamper the positive valence of the rating [28].

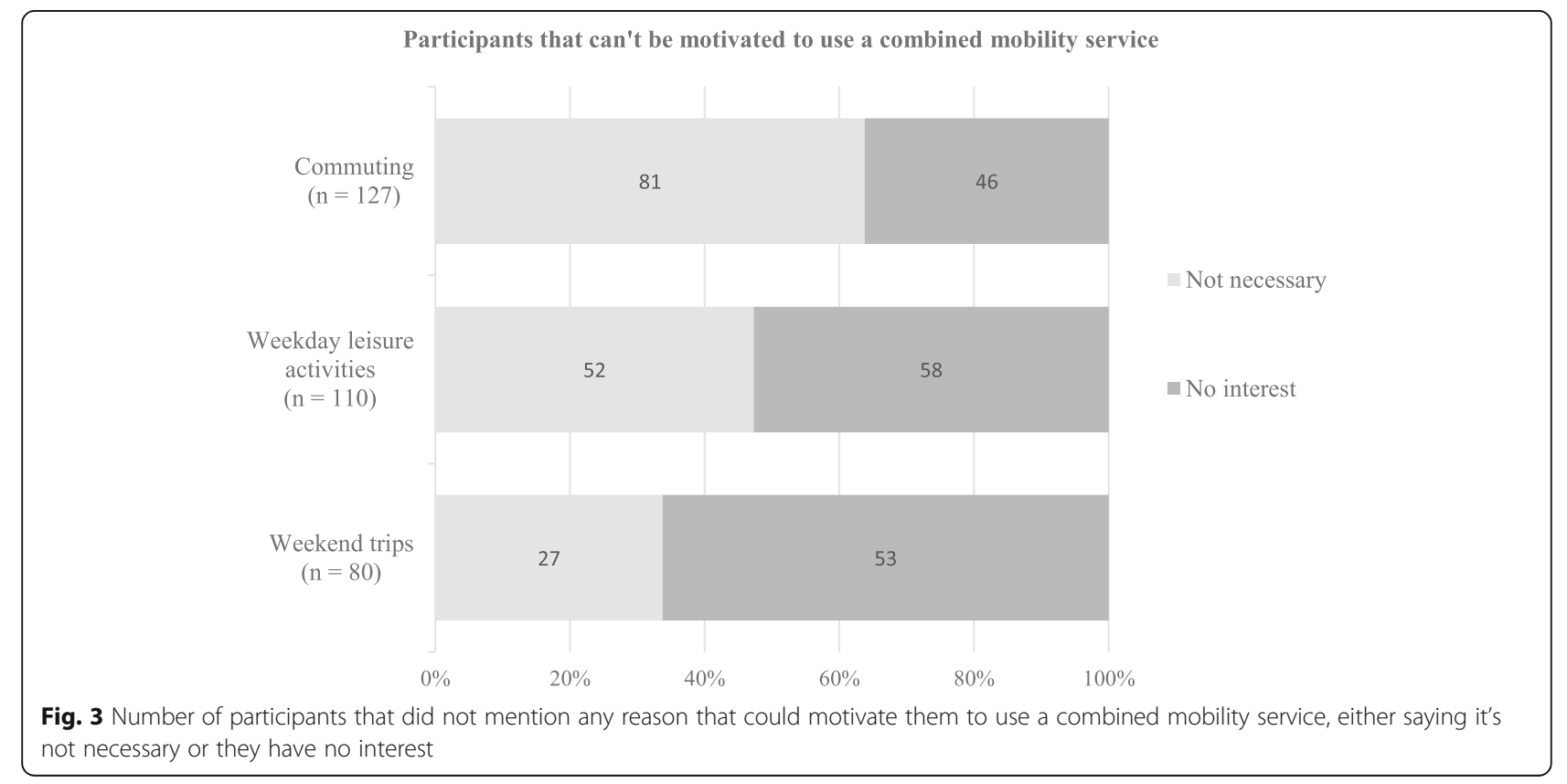


For those participants that were not open to trying a MaaS service, the most important aspects to potentially change their minds are spontaneous availability/ flexibility, cheaper price than current modes and being independent. This is not surprising since the majority of participants use their car predominantly for leisure activities, which have a high level of flexibility and independence. Due to the user-centric approach of MaaS as well as the strong focus on sharing, cost reductions are possible [3, 13]. Clear communication of these cost reductions might be helpful since the price of mobility is generally perceived as high in Switzerland [24] and lower prices would have a positive effect on openness to using MaaS. What is most striking, however, is the high number of participants who feel there is no need for such a combined mobility service for commuting (81 in Fig. 3). Respondents in this study claimed to use public transport for commuting more often than using a private car. As such, people might not see the need for an additional service when the train, bus or tram they usually take already satisfies their travel needs (see also Ho et al. [21]). The lack of need for MaaS declines for weekday leisure trips and even more for weekend leisure trips. This is encouraging since nearly half of the participants currently use a private car for leisure trips (see Table 3), a trend which could be effectively countered by the flexibility and mode variability of MaaS concepts in leisure route planning. Luggage storage possibilities and, to a lesser degree, privacy were also mentioned as motivators to use Maas for leisure activities, although they do not seem to be relevant to commuting. A constant number of 46 to 58 participants could not be motivated to use a combined mobility service in any way (no interest), reflecting aversion to change. However, in relation to the total of 995 study participants, the actual number of "unchangeable minds" is quite small.

MaaS is a new concept for most people. Despite the short text explaining the MaaS concept to all participants, it is possible that not all of them fully understood its potential. As it is based on an online survey, the current study certainly has some additional limitations with respect to its validity. The share of higher education graduates, for example, is above the Swiss average, and one has to be aware of common biases of participants when responding to surveys. Furthermore, the treatment samples were rather small. Last, it has to be noted that we conducted the survey in Switzerland, where digital travel information platforms are well developed but no fully operational MaaS service exists. Despite a long history of carsharing, strong popularity of scooter-sharing and a reliable public transport network, the awareness of the MaaS concept might be different than in other countries.

\section{Concluding remarks}

With this paper, we provide an important addition to the literature on MaaS by investigating factors and needs that would motivate the use of such a combined mobility service. By separately analysing three distinct trip purposes, commuting, weekday leisure trips and weekend leisure trips, we provide additional insights into potential MaaS users compared to previous studies.

Based on a comprehensive online survey in Switzerland, we find that openness to using MaaS for commuting is lowest. Still, those who plan to reduce their car usage might be motivated to switch to a seamless travel service if it is sufficiently flexible and fast. For leisure activities, on the other hand-for which most people use their private car-a different set of factors is relevant. Here, higher education and previous experience with carsharing significantly increased openness to using MaaS. Further, the participants see MaaS as a sustainable alternative; as such, pro-environmental attitudes as well as announcements of future consumer-addressing policy measures would increase openness to use. Generally, participants that predominantly use public transport for travelling are more open to using MaaS than those who predominantly travel by private car. This result implies some challenges for one of the core expectations of MaaS-to reduce private vehicle ownership. We would thus encourage an increased focus on this group as well as develop MaaS services that target the following three key commuting needs: spontaneity, lower costs and short transfer times. For leisure trips (both weekday and weekend trips), we emphasize not only looking at spontaneity and lower price but also independence and luggage storage possibilities.

Overall, we conclude that providing information and experience is key in designing such combined mobility services. Future studies should pay attention to the differences in needs and motives for using MaaS for commuting and leisure trips. Once MaaS services become more widely available, large-scale surveys could benefit from a more established technical jargon that could mitigate biases due to misunderstandings. Furthermore, MaaS also benefits from the increasing popularity of sharing systems such as car-, bike- and scooter-sharing. Having some experience with such programs has been shown to increase openness to using MaaS. As MaaS is still in its infancy, preferences might continuously change, calling for regular research into these preferences and the needs of potential users. 


\section{Appendix 1}

Table 5 Example of treatment 2 (five-star rating of a combined mobility service)

\begin{tabular}{|l|l|l|}
\hline Public transport & \\
Car with driver \\
(e.g. Taxi, Uber)
\end{tabular}

\section{Appendix 2}

Table 6 Example of treatment 3 \& 4

\begin{tabular}{|c|c|}
\hline T3 (policy planned) & T4 (policy decided) \\
\hline $\begin{array}{l}\text { With the Paris Climate Agreement the international community of states } \\
\text { aims to keep global warming below } 2 \text { degrees. Following that, the Swiss } \\
\text { government has defined a target to reduce national emissions by 50\% } \\
\text { compared to } 1990 \text { levels. Since the transportation sector is responsible } \\
\text { for a large share of total CO2 emissions in Switzerland, one central } \\
\text { climate policy pillar addresses mobility and transportation. } \\
\text { Across the world one can observe similar efforts. The Chinese } \\
\text { Government aims to achieve a quota of at least } 8 \text { percent of electric cars } \\
\text { by } 2019 \text {, rising up to } 20 \% \text { in } 2025 \text {. To fulfil this target, they introduced a } \\
\text { fixed sales quota for car suppliers, but also implemented various policies } \\
\text { directly addressing consumers, such as the introduction of different } \\
\text { number plates (with restricted quantities for non-electric cars). Other } \\
\text { countries abolished highway fees for electric cars (Norway) or increased } \\
\text { fuel levies (France). Oxford decided to ban all diesel and fuel-powered } \\
\text { cars in the city centre from } 2020 \text { onwards and similar policies are dis- } \\
\text { cussed in several German cities. } \\
\text { Assume now, that the Swiss government has announced, that it wants to } \\
\text { achieve a new sales quota of } 20 \% \text { of electric cars by } 2023 \text {. } \\
\text { The policy to achieve this target has not been defined yet and is } \\
\text { matter of discussion in the parliament. }\end{array}$ & $\begin{array}{l}\text { With the Paris Climate Agreement the international community of states } \\
\text { aims to keep global warming below } 2 \text { degrees. Following that, the Swiss } \\
\text { government has defined a target to reduce national emissions by 50\% } \\
\text { compared to } 1990 \text { levels. Since the transportation sector is responsible } \\
\text { for a large share of total CO2 emissions in Switzerland, one central } \\
\text { climate policy pillar addresses mobility and transportation. } \\
\text { Across the world one can observe similar efforts. The Chinese } \\
\text { Government aims to achieve a quota of at least } 8 \text { percent of electric cars } \\
\text { by } 2019 \text {, rising up to } 20 \% \text { in 2025. To fulfil this target, they introduced a } \\
\text { fixed sales quota for car suppliers, but also implemented various policies } \\
\text { directly addressing consumers, such as the introduction of different } \\
\text { number plates (with restricted quantities for non-electric cars). Other } \\
\text { countries abolished highway fees for electric cars (Norway) or increased } \\
\text { fuel levies (France). Oxford decided to ban all diesel and fuel-powered } \\
\text { cars in the city centre from } 2020 \text { onwards and similar policies are dis- } \\
\text { cussed in several German cities. } \\
\text { Assume now, that the Swiss government has announced, that it wants to } \\
\text { achieve a new sales quota of } 20 \% \text { of electric cars by } 2023 \text {. } \\
\text { From } \mathbf{2 0 2 0} \text { onwards several measures will be implemented step- } \\
\text { wise, such as increasing fuel levies, vehicle import restrictions and a } \\
\text { ban of non-electric vehicles in the city centre. }\end{array}$ \\
\hline
\end{tabular}

\section{Appendix 3}

Table 7 Wording of environmental attitude questions summarized as one pro-environmental attitude variable Likert scale: 1 - totally disagree to 5 - totally agree

PROUD when I act in an environmentally friendly manner HAPPY when I conserve or avoid wasting natural resources

\section{GUILTY when I harm the environment}

APPRECIATION towards others when they act in an environmentally friendly manner

WARM towards others when they conserve or avoid wasting natural resources
Table 7 Wording of environmental attitude questions summarized as one pro-environmental attitude variable (Continued)

CONTENT when I act in an environmentally friendly manner

INDIGNANT when others act in an environmentally unfriendly manner REGRET when I waste natural resources

ANGRY when others act in an environmentally unfriendly manner ASHAMED when I act in an environmentally unfriendly manner DISGUSTED when others waste natural resources POSITIVE towards others when they act environmentally friendly 


\section{Abbreviations}

DV: Dependent variable; EV: Electric vehicle; IV: Independent variable; MaaS: Mobility-as-a-Service; SHEDS: Swiss Household Energy Demand Survey; VIF: Variance inflation factor

\section{Acknowledgements}

The study strongly benefitted from the access provided to the SHEDS database.

\section{Authors' contributions}

$\mathrm{RH}$ and $\mathrm{AS}$ designed the questionnaire and experiments of the study. $\mathrm{RH}$ conducted the regression analysis. $\mathrm{RH}$ and AS prepared the draft manuscript. $\mathrm{RH}, \mathrm{AS}, \mathrm{AP}$ and $\mathrm{AD}$ analysed and interpreted the results. All authors read and approved the final manuscript.

\section{Funding}

This research was supported by the Swiss Competence Center for Energy Research (SCCER) Efficient Technologies and Systems for Mobility, funded by Innosuisse. The research has also been carried out with the support of the Swiss Federal Office of Energy (SFOE, grant number SI/501562-01). The authors bear sole responsibility for the conclusions and findings.

\section{Availability of data and materials}

The datasets used in the study are available from the corresponding author on reasonable request.

\section{Competing interests}

The authors declare that they have no competing interests.

\section{Author details}

'Institute for Sustainable Development, Zurich University of Applied Sciences (ZHAW), Technikumstrasse 9, 8401 Winterthur, Switzerland. ${ }^{2}$ Center for Economic Research, MTEC, Swiss Federal Institute of Technology (ETH), Zürichbergstrasse 18, 8092 Zurich, Switzerland. ${ }^{3}$ Institute for Environmental Decisions, Swiss Federal Institute of Technology (ETH), Universitätsstrasse 16, 8092 Zurich, Switzerland.

\section{Received: 5 July 2019 Accepted: 8 March 2020}

\section{Published online: 07 May 2020}

\section{References}

1. Abdi, H. (2012). Holm's sequential Bonferroni procedure. In N. J. Salkind (Ed.), Encyclopedia of Research Design (pp. 574-577). https://doi.org/10.4135/ 9781412961288.n178 Accessed 16 Apr 2019.

2. Allison, P. D. (1999). Logistic regression using the SAS system: Theory and application. Cary: SAS Institute Inc.

3. Baptista, P., Melo, S., \& Rolim, C. (2014). Energy, environmental and mobility impacts of Car-sharing systems. Empirical results from Lisbon, Portugal. Procedia - Social and Behavioral Sciences, 111, 28-37. https://doi.org/10.1016/ j.sbspro.2014.01.035.

4. Becker, H., Ciari, F., \& Axhausen, K. W. (2017a). Comparing car-sharing schemes in Switzerland: User groups and usage patterns. Transportation Research Part A: Policy and Practice, 97, 17-29. https://doi.org/10.1016/j.tra. 2017.01.004

5. Becker, H., Ciari, F., \& Axhausen, K. W. (2017b). Modeling free-floating carsharing use in Switzerland: A spatial regression and conditional logit approach. Transportation Research Part C: Emerging Technologies, 81, 286299. https://doi.org/10.1016/j.trc.2017.06.008.

6. BFS, \& ARE. (2017). Verkehrsverhalten der Bevölkerung. Ergebnisse des Mikrozensus Mobilität und Verkehr 2015 (p. 88) https://www.bfs.admin.ch/bfs/ de/home/statistiken/mobilitaet-verkehr/personenverkehr/verkehrsverhalten. assetdetail.1840477.html. Accessed 16 Apr 2019

7. Bretschger, L., \& Soretz, S. (2018). Stranded Assets: How Policy Uncertainty Affects Capital, Growth, and the Environment (SSRN scholarly paper no. ID 3157079). https://papers.ssrn.com/abstract=3157079. Accessed 16 Apr 2019.

8. Bundesamt für Statistik. (2018a). Household income and expenditure. https://www.bfs.admin.ch/bfs/en/home/statistiken/wirtschaftliche-sozialesituation-bevoelkerung/einkommen-verbrauch-vermoegen/haushaltsbudget. html. Accessed 16 Apr 2019.
9. Bundesamt für Statistik. (2018b). Population. https://www.bfs.admin.ch/bfs/ en/home/statistiken/bevoelkerung/stand-entwicklung/bevoelkerung.html. Accessed 16 Apr 2019

10. Bundesamt für Statistik. (2019). Bildungsstand. https://www.bfs.admin.ch/bfs/ de/home/statistiken/bildung-wissenschaft/bildungsstand-kompetenzen.html. Accessed 16 Apr 2019.

11. Ciari, F., \& Becker, H. (2017). How Disruptive Can Shared Mobility Be? A Scenario-Based Evaluation of Shared Mobility Systems Implemented at Large Scale. In G. Meyer \& S. Shaheen (Eds.), Disrupting Mobility: Impacts of Sharing Economy and Innovative Transportation on Cities (pp. 51-63). https:// doi.org/10.1007/978-3-319-51602-8_3.

12. Curtis, C., \& Headicar, P. (1997). Targeting travel awareness campaigns: Which individuals are more likely to switch from car to other transport for the journey to work? Transport Policy, 4(1), 57-65. https://doi.org/10.1016/ S0967-070X(96)00034-0.

13. Danielis, R., Rotaris, L., Rusich, A., \& Valeri, E. (2014). Understanding the demand for carsharing: Lessons from Italian case studies. 41(3). https://ideas. repec.org/a/jte/journl/20143412.html. Accessed 16 Apr 2019.

14. Ditmore, C. J., \& Deming, D. M. (2018). Vanpooling and its effect on commuter stress. Research in Transportation Business \& Management, 27, 98106. https://doi.org/10.1016/j.rtbm.2018.11.001.

15. Fairley, P. (2013). Car sharing could be the EV's killer app. IEEE Spectrum, 50(9), 14-15. https://doi.org/10.1109/MSPEC.2013.6587173.

16. Gaker, D., Zheng, Y., \& Walker, J. (2010). Experimental economics in transportation focus on social influences and provision of information. Transportation Research Record, 2156, 47-55. https://doi.org/10.3141/ 2156-06.

17. Glotz-Richter, M. (2016). Reclaim street space! - Exploit the European potential of Car sharing. Transportation Research Procedia, 14, 1296-1304. https://doi.org/10.1016/j.trpro.2016.05.202

18. Heikkilä, S. (2014). Mobility as a service - a proposal for action for the public administration, Case Helsinki. https://aaltodoc.aalto.fi:443/handle/123456 789/13133. Accessed 16 Apr 2019.

19. Hietanen, S. (2014). 'Mobility as a service' - the new transport model? Eurotransport, 12(2), 2-4.

20. Ho, C. Q., Hensher, D. A., Mulley, C., \& Wong, Y. Z. (2018). Potential uptake and willingness-to-pay for mobility as a service (MaaS): A stated choice study. Transportation Research Part A: Policy and Practice, 117, 302-318. https://doi.org/10.1016/j.tra.2018.08.025.

21. Ho, C. Q., Mulley, C., \& Hensher, D. A. (2019). Public preferences for mobility as a service: Insights from stated preference surveys. Transportation Research Part A: Policy and Practice. https://doi.org/10.1016/j.tra.2019.09.031.

22. Hoerler, R., Haerri, F., \& Hoppe, M. (2019). New solutions in sustainable commuting - The attitudes and experience of European stakeholders and experts in Switzerland. Social Sciences, 8(7), 220. https://doi.org/10.3390/ socsci8070220.

23. Hoerler, R., \& Hoppe, M. (2019). Commuter segmentation and openness to sharing services: A Swiss case study (p. 18) [working paper]. Retrieved from ZHAW website: https://digitalcollection.zhaw.ch/handle/11475/18749.

24. Hoppe, M., Hoerler, R., \& Haerri, F. (2018). ENSCC Smart and Mobile Work in Growth Regions - Smart Commuting (p. 248) https://www.aramis.admin.ch/ Default.aspx? DocumentID=50001\&load=true. Accessed 16 Apr 2019.

25. Jittrapirom, P., Caiati, V., Feneri, A.-M., Ebrahimigharehbaghi, S., González, M. J. A., \& Narayan, J. (2017). Mobility as a service: A critical review of definitions, assessments of schemes, and key challenges. Urban Planning, 2(2), 13-25. https://doi.org/10.17645/up.v2i2.931.

26. King, R. G., Lu, Y. K., \& Pastén, E. S. (2008). Managing expectations. Journal of Money, Credit and Banking, 40(8), 1625-1666. https://doi.org/10.1111/j.15384616.2008.00177.x.

27. Lempert, R., Zhao, J., \& Dowlatabadi, H. (2019). Convenience, savings, or lifestyle? Distinct motivations and travel patterns of one-way and two-way carsharing members in Vancouver, Canada. Transportation Research Part D: Transport and Environment, 71, 141-152. https://doi.org/10.1016/j.trd.2018.12. 010.

28. Lüders, M., Andreassen, T. W., Clatworthy, S., \& Hillestad, T. (2017). Innovating for Trust. Cheltenham: Edward Elgar Publishing.

29. MaaS Alliance. (2019). What is MaaS? https://maas-alliance.eu/homepage/ what-is-maas/. Accessed 16 Apr 2019

30. Matyas, M., \& Kamargianni, M. (2018). Exploring individual preferences for mobility as a service plans: A mixed methods approach (MaaSLab working paper series no. 18-02) (p. 26). 
31. Matyas, M., \& Kamargianni, M. (2019). The potential of mobility as a service bundles as a mobility management tool. Transportation, 46(5), 1951-1968. https://doi.org/10.1007/s11116-018-9913-4.

32. Moosa, I., Puican, L., Ramiah, V., Morris, T., \& Gangemi, M. (2016). The effects of announcement of green policies on equity portfolios: Evidence from the United Kingdom. Managerial Auditing Journal, 31(2), 138-155. https://doi. org/10.1108/MAJ-08-2014-1065.

33. Mounce, R., \& Nelson, J. D. (2019). On the potential for one-way electric vehicle car-sharing in future mobility systems. Transportation Research Part A: Policy and Practice, 120, 17-30. https://doi.org/10.1016/j.tra.2018.12.003.

34. Mulley, C., Nelson, J. D., \& Wright, S. (2018). Community transport meets mobility as a service: On the road to a new a flexible future. Research in Transportation Economics, 69, 583-591. https://doi.org/10.1016/j.retrec.2018. 02.004.

35. Münzel, K., Boon, W., Frenken, K., Blomme, J., \& van der Linden, D. (2019). Explaining carsharing supply across Western European cities. International Journal of Sustainable Transportation, 0(0), 1-12. https://doi.org/10.1080/ 15568318.2018 .1542756$.

36. Nook, E. C., Ong, D. C., Morelli, S. A., Mitchell, J. P., \& Zaki, J. (2016). Prosocial conformity: Prosocial norms generalize across behavior and empathy. Personality and Social Psychology Bulletin, 42(8), 1045-1062. https://doi.org/ 10.1177/0146167216649932.

37. Park, S., \& Shin, J. (2017). The influence of anonymous peers on prosocial behavior. PLoS One, 12(10), e0185521. https://doi.org/10.1371/journal.pone. 0185521.

38. Rasouli, S., \& Timmermans, H. (2016). Influence of social networks on latent choice of electric cars: A mixed Logit specification using experimental design data. Networks and Spatial Economics, 16(1), 99-130. https://doi.org/ 10.1007/s11067-013-9194-6.

39. Rudorf, S., Baumgartner, T., \& Knoch, D. (2019). Peer effects on control-averse behavior. Scientific Reports, 9(1), 3012. https://doi.org/10.1038/s41598-01939600-9.

40. Russ, M., \& Tausz, K. (2015). Mobilität als Service - Nutzerorientierung als Paradigma zwischen Markt und öffentlicher Grundvorsorge. e \& i Elektrotechnik und Informationstechnik, 132(7), 404-408. https://doi.org/10. 1007/s00502-015-0341-2

41. Santos, G. (2018). Sustainability and Shared Mobility Models. Sustainability, 10(9), 3194. https://doi.org/10.3390/su10093194.

42. Schikofsky, J., Dannewald, T., \& Kowald, M. (2020). Exploring motivational mechanisms behind the intention to adopt mobility as a service (MaaS): Insights from Germany. Transportation Research Part A: Policy and Practice, 131, 296-312. https://doi.org/10.1016/j.tra.2019.09.022.

43. Schlüter, J., \& Weyer, J. (2019). Car sharing as a means to raise acceptance of electric vehicles: An empirical study on regime change in automobility. Transportation Research Part F: Traffic Psychology and Behaviour, 60, 185-201. https://doi.org/10.1016/j.trf.2018.09.005.

44. Schmidt, T. S., Schneider, M., Rogge, K. S., Schuetz, M. J. A., \& Hoffmann, V. H. (2012). The effects of climate policy on the rate and direction of innovation: A survey of the EU ETS and the electricity sector. Environmental Innovation and Societal Transitions, 2, 23-48. https://doi.org/10.1016/j.eist.2011.12.002.

45. Shaheen, S. A., \& Cohen, A. P. (2013). Carsharing and personal vehicle services: Worldwide market developments and emerging trends. International Journal of Sustainable Transportation, 7(1), 5-34. https://doi.org/ 10.1080/15568318.2012.660103.

46. Sochor, J., Arby, H., Karlsson, I. C. M., \& Sarasini, S. (2018). A topological approach to mobility as a service: A proposed tool for understanding requirements and effects, and for aiding the integration of societal goals. Research in Transportation Business \& Management, 27, 3-14. https://doi.org/ 10.1016/j.rtbm.2018.12.003.

47. Sochor, J., Strömberg, H., \& Karlsson, I. C. M. (2015). Implementing mobility as a service: Challenges in integrating user, commercial, and societal perspectives. Transportation Research Record, 2536(1), 1-9. https://doi.org/10. 3141/2536-01

48. Sovacool, B. K., Kester, J., Noel, L., \& de Rubens, G. Z. (2018). The demographics of decarbonizing transport: The influence of gender, education, occupation, age, and household size on electric mobility preferences in the Nordic region. Global Environmental Change, 52, 86-100 https://doi.org/10.1016/j.gloenvcha.2018.06.008.

49. Sparks, B., \& Browning, V. (2011). The impact of online reviews on hotel booking intentions and perception of trust. Tourism Management, 32(6), 1310-1323. https://doi.org/10.1016/j.tourman.2010.12.011.
50. Storme, T., De Vos, J., De Paepe, L., \& Witlox, F. (2019). Limitations to the carsubstitution effect of MaaS. Findings from a Belgian pilot study. Transportation Research Part A: Policy and Practice. https://doi.org/10.1016/j. tra.2019.09.032.

51. Stünzi, A. (2019). Acceptance of stringent climate policy: The use of policy announcements to reduce individuals' stranded assets. Zurich: ETH Zurich.

52. Szaszi, B., Palinkas, A., Palfi, B., Szollosi, A., \& Aczel, B. (2018). A systematic scoping review of the choice architecture movement: Toward understanding when and why nudges work. Journal of Behavioral Decision Making, 31(3), 355-366. https://doi.org/10.1002/bdm.2035.

53. Tyndall, J. (2019). Free-floating carsharing and extemporaneous public transit substitution. Research in Transportation Economics, 74, 21-27. https:// doi.org/10.1016/j.retrec.2019.01.005.

54. Weber, S., Burger, P., Farsi, M., Martinez-Cruz, A. L., Puntiroli, M., Schubert, I., \& Volland, B. (2017). Swiss Household Energy Demand Survey (SHEDS): Objectives, design, and implementation (working paper no. 17-14). https:// www.econstor.eu/handle/10419/191509. Accessed 16 Apr 2019.

55. Wilson, C., Pettifor, H., Cassar, E., Kerr, L., \& Wilson, M. (2019). The potential contribution of disruptive low-carbon innovations to $1.5^{\circ} \mathrm{C}$ climate mitigation. Energy Efficiency, 12(2), 423-440. https://doi.org/10.1007/s12053018-9679-8.

56. Ye, R., \& Titheridge, H. (2017). Satisfaction with the commute: The role of travel mode choice, built environment and attitudes. Transportation Research Part D: Transport and Environment, 52, 535-547. https://doi.org/10. 1016/j.trd.2016.06.011.

57. Yoon, T., Cherry, C. R., Ryerson, M. S., \& Bell, J. E. (2019). Carsharing demand estimation and fleet simulation with EV adoption. Journal of Cleaner Production, 206, 1051-1058. https://doi.org/10.1016/j.jclepro.2018.09.124.

\section{Publisher's Note}

Springer Nature remains neutral with regard to jurisdictional claims in published maps and institutional affiliations.

\section{Submit your manuscript to a SpringerOpen ${ }^{\circ}$ journal and benefit from:}

- Convenient online submission

- Rigorous peer review

- Open access: articles freely available online

High visibility within the field

- Retaining the copyright to your article

Submit your next manuscript at $\boldsymbol{\nabla}$ springeropen.com 